\title{
Significant SPACES: The Role of Marine Ecosystems in Pacific Island Cultures
}

\section{Transforming Cultures eJournal, \\ Vol. 1 No. 2, June 2006 \\ http://epress.lib.uts.edu.au/journals/TfC}

\section{Paul D'Arcy \\ James Cook University}

Recent scholarship on the collapse of Rapanui (Easter Island) society as a result of selfinflicted environmental degradation has inadvertently raised the international profile of Pacific islands as small, bounded and vulnerable ecosystems. ${ }^{1}$ The history of Rapanui is not typical however. Most of the inhabitants of Remote Oceania were not bound by the sea, but rather embraced it as both habitat and pathway to resources and opportunities beyond their home islands.

Academic neglect of the sea as a factor in Pacific history ignores its central role in islander actions and narratives. Before the imposition of colonial rule, islanders spent much time in and on the ocean, drawing sustenance from it, mapping it, fighting over it, and deriving a sense of identity from it. Such a world created a wider sense of community and belonging. Perhaps the most articulate voice for this new vision has been Epeli Hau’ofa. In his 1994 article “Our Sea of Islands”, Hau’ofa asserts that:

The world of our ancestors was a large sea full of places to explore, to make their homes in, to breed generations of seafarers like themselves. People raised in this environment were at home with the sea. They played in it as soon as they could walk steadily, they worked in it, they fought on it. They developed great skills for navigating their waters, and the spirit to traverse even the few large gaps that separated their island groups.

Theirs was a large world in which peoples and cultures moved and mingled, unhindered by boundaries of the kind erected much later by imperial powers. ${ }^{2}$

\footnotetext{
${ }^{1}$ See Paul Bahn, P. \& John Flenley (1992) Easter Island Earth Island, London: Thames and Hudson; and Jared Diamond (25 March 2004) “Twilight at Easter", New York Review of Books, pp. 6-10. This paper was improved by taking account of thoughtful suggestions made by two anonymous referees. The author is grateful for their kind comments and assistance.

2 Epeli Hau'ofa (1994) “Our Sea of Islands”, The Contemporary Pacific, vol.6(1), pp.148-61, pp.153-154.
} 
This vision was a response to outsider stereotypes of small island nations as 'basket cases'. The classic statement of this viewpoint was an article published in 1985 by Geoffrey Bertram and Ray Watters which asserted that smaller Pacific Island nation states were dependent on aid and remittances and would remain so into the future ${ }^{3}$ : this image still appears to dominate the thinking of many Australian policy analysts concerned with Australia's relations with its Pacific neighbours. ${ }^{4}$ Hau'ofa argues that these 'basket cases' were the result of barriers created by colonial boundaries and policies that imposed an artificial sense of isolation and separation upon Islanders. Islanders must now de-colonise their minds, and recast their sense of identity by rediscovering the vision of their ancestors for whom the Pacific was a boundless sea of possibilities and opportunities.

His vision of ancestors who held an expansive view of their realm is closer to reality than other scholars admit. ${ }^{5}$ Few Island communities were restricted to one island.

Prior to European colonial rule, Pacific Islanders had a close relationship with the sea. Most lived along the coastal margins of their island homes. For most of the region's inhabitants the sea was integral to daily life. The sights, sounds and smells of the sea pervaded their daily existence, while the tastes of the sea were often on their lips. Marine species made up a significant part of the diet. Members of Cook's expeditions recorded 150 types of fish known by Tahitians in the 1770s, at least 48 of which were identified as edible. ${ }^{6}$ Salt made from evaporated seawater was a valued addition to the diet.

\footnotetext{
${ }^{3}$ Geoffrey Bertram \& Ray Watters (1985) "The MIRAB Economy and South Pacific Microstates", Pacific Viewpoint, 26(3), pp. 497-519.

${ }^{4}$ See, for example, Helen Hughes (7 May 2003) "Aid has failed the Pacific", Issue Analysis no. 33, Centre for Independent Studies. While Hughes maintains that privatization offers a way out of dependency on external aid and remittance funding, she provides few detailed examples of how such policies can and will replace this income and overcome island nations' underlying problems of providing services for small, scattered populations, distance from markets, and economies of scale.

${ }^{5}$ See, for example, Patrick V. Kirch \& Roger C. Green (2001) Hawaiki, Ancestral Polynesia: an essay in historical anthropology, Cambridge: Cambridge University Press, especially pp. 86-89.

${ }^{6}$ Gordon R. Lewthwaite (1996) "Man and the Sea in Early Tahiti: Maritime Economy through European Eyes”, Pacific Viewpoint, 7(1), pp. 28-53, p. 34, citing J.R. Forster, Observations made during a Voyage round the World, G. Robinson, London, 1778, pp. 440-441.
} 
Islanders felt at ease in the sea, and excelled at swimming. The missionary William Ellis went so far as to describe Hawai'ians as "almost a race of amphibious beings."7 Numerous European observers were struck by how comfortable Islanders were in the water, and often described them in terms usually reserved for marine creatures. They noted that Islanders derived great joy from being in the sea. Water sports and activities were popular with adults - body, board and canoe surfing; diving; canoe races; and swimming races. ${ }^{8}$

\section{The sea in thoughts and beliefs}

The extraordinary role played by water in the lives of Islanders influenced their perception of the sea. Marine creatures were considered to be much more than a source of food. The categories that modern scientists use to classify the ocean and the life forms inhabiting it bear little resemblance to those traditionally used by Islanders. In their world all things were connected; fish might be seen as relatives as well as food, and gods and ancestors could take multiple forms. Instead of being relegated to the world of the 'supernatural' as they tend to be today, spiritual beings attributed to marine life figured in the daily lives of Islanders.

Signs sent from the gods might consist of natural phenomena such as thunder, or the actions of species associated with a particular god or ancestral spirit. The Tongan god Taufa might manifest himself in his priest Kautae, in a shark, or in a gecko. Such species were conceived of as vaka, (vessels) of the god. ${ }^{9}$ Immediate and personal links connected marine creatures and humans. Fish might be manifestations of people who died at sea, particularly those who had drowned.

Islanders' perceptions of the sea reflected both their practical knowledge as fishers and sailors, and their cultural beliefs in a world where gods, spirits, humans and other

\footnotetext{
${ }^{7}$ William Ellis (1969) Polynesian Researches: Hawaii, Rutland, Vermont: Charles E. Tuttle Co. Publishers (reprint of new edition, 1842), p. 369.

${ }^{8}$ On the use of the sea for childhood and adult leisure see Ben R. Finney (1984) "The Ocean and the Quality of Life", in Chennat Gopalakrishnan (ed.), The Emerging Marine Economy of the Pacific, London: Butterworths, pp. 187-192, especially p. 189; David Malo (1951) Hawaiian Antiquities: Moolelo Hawaii, $2^{\text {nd }}$ edition (English translation by Nathanial B. Emerson), Honolulu: Bishop Museum, pp. 223224, 233; Dorothy Barrere (ed.) (1983) Fragments of Hawaiian History, by John Papa Ii (English translation by Mary Kawena Pukui), Honolulu: Bishop Museum, pp. 131-133; Teuira Henry (1928) Ancient Tahiti, Honolulu: BPBM, pp. 278-279.

${ }^{9}$ E.W. Gifford (1929) Tongan Society, Honolulu: Bishop Museum, p. 288.
} 
creatures existed side by side. The most complete picture of Islanders' perception of the ocean in the nineteenth century comes from Hawai'i. Descriptions of the zones and moods of the sea recognized by Hawai'ians are almost as detailed as their terrestrial equivalents. The zones were named according to their colour, motion, wave action, tides and the type of fishing conducted there. ${ }^{10}$

\section{The Sea as a Highway}

The seas of Oceania were bridges rather than barriers. Mobility was integral to the yearly cycle for most Oceanic communities. A web of social, economic and political ties linked them with other communities and localities. The sheer volume of movement across the sea of islands attests to Islanders willingness and ability to travel. Islanders travelled mainly by sea, even to destinations on the same island. Pathways over land were generally poorly developed.

Many coastal communities could transport the majority of their population by canoe. European explorers were often confronted by a host of canoes. Long voyages between archipelagos were still being undertaken in several areas into the nineteenth century. Regular voyaging occurred between the Societies and Tuamotus in central Eastern Polynesia, between Tonga, Samoa and Fiji in Western Polynesia, and between the atolls of the Western Carolines and their high island neighbours in Micronesia. ${ }^{11}$

Islanders usually waited for favourable winds rather than risk sailing in dangerous winds. Records garnered since 1770 suggest that Islanders were remarkably skilled at avoiding dangerous sea conditions. While studying the traditional navigational ability of Puluwatese in the 1960s, Thomas Gladwin noted that 73 voyages were conducted in 16 months without any mishap. Up to 1970 the last Puluwatese fatality at sea had occurred in 1945 when a canoe was lost during a typhoon. ${ }^{12}$

\footnotetext{
${ }^{10}$ The following account of Hawai'ian conceptions of the sea is based on Malo (1951:16-18, 26).

${ }^{11}$ David Lewis (1977) From Maui to Cook. The Discovery and Settlement of the Pacific, Lane Cove, New South Wales: Doubleday, p. 29; Ben R. Finney (1979) "Voyaging", in Jesse D. Jennings (ed.) The Prehistory of Polynesia, Canberra: Australian National University, pp. 324-351, pp. 349-350; and Geoffrey Irwin (1992) The Prehistoric Exploration and Colonisation of the Pacific. Cambridge: Cambridge University Press, pp. 213-214.

12 Thomas Gladwin (1970) East is a Big Bird: Navigation and Logic on Puluwat Atoll, Cambridge, Mass.: Harvard University Press, p. 63.
} 
The people of the sea travelled beyond their immediate landscapes and seascapes for a variety of reasons. Most communities could gain access to valuables through exchanges with other communities. The social ties forged by such relationships could be called upon in times of need, such as drought or the aftermath of storms. ${ }^{13}$ A combination of small islands and regional networks made most oceanic communities highly localised in their affinities, and expansive, even regional, in their interactions. Most Islanders embraced multiple cultural affinities, both local and regional.

The openness of the island world meant that natural and human influences from beyond the horizon often resulted in periods of rapid change. The sea has many moods, and its more violent ones influenced the course of history. Natural hazards continue to disrupt and endanger the lives of Pacific communities into the present day as the tsunami that decimated villages on the north coast of Papua New Guinea at Aitape in July 1998.

Through their sea travels Islanders knew about or suspected the existence of worlds beyond their usual voyaging range. Expectations of forces from beyond the horizon were deeply embedded in their worldviews long before the tall ships of Europeans sailed into view. Centuries of experience had taught them that new lands, new opportunities and new and old threats hovered just beyond the horizon.

Island history also taught that strangers from beyond the horizon periodically came to overthrow rulers. Islander political and social philosophy centred on the idea of melding local and exotic elements. Usurping strangers from beyond the horizon pervade many traditional histories. Rulers who offended their people could not rely on their support when the next usurper arrived, and might even face a challenge from within. ${ }^{14}$

\section{Colonial Atrophy}

One group of outsiders dramatically altered Islanders' relationships with the sea. European colonial activities and regulations reined in Islanders' inter-island mobility as never before. In Micronesia, the Japanese authorities forbade long distance canoe travel

\footnotetext{
${ }^{13}$ For example see William H. Alkire (1970) "Systems of Measurement on Woleai Atoll, Caroline Islands”, Anthropos, 65: 1-73, especially pp. 6-7, 66-67; and W. Alkire (1978) Coral Islanders, Illinois, Arlington Heights: AHM Publishing Corporation, pp. 119-120.

${ }^{14}$ See for example Samuel Kamakau (1961) Ruling Chiefs of Hawaii, Honolulu: Kamehameha Schools Press, p. 143 on Hawai'i.
} 
in the name of safety. The development of regular inter-island shipping services reduced low islanders' reliance on kin for disaster relief. German and Japanese colonial authorities used government vessels to ferry supplies to storm ravaged areas or to evacuate refugees. ${ }^{15}$

Colonial prohibitions on inter-island canoe travel were widespread - from the British Gilbert Islands to French Polynesia. ${ }^{16}$ Arbitrary colonial boundaries divided the Pacific into spheres of European interest, while policies eroded Islanders' means of independent travel. Tongan scholar Epeli Hau'ofa sees this as one of the most destructive legacies of the colonial era:

Nineteenth-century imperialism erected boundaries that lead to the contraction of Oceania, transforming a once boundless world into the Pacific Island states and territories that we know today. People were confined to their tiny spaces, isolated from each other. No longer could they travel freely to do what they had done for centuries. They were cut off from their relatives abroad, from their far-flung sources of wealth and cultural enrichment. This is the historical basis of the view that our countries are small, poor and isolated. It is true only insofar as people are still fenced in and quarantined. ${ }^{17}$

While factually correct, Hau'ofa's representation is only a partial picture. Regular Western shipping services and the peace imposed by colonial authorities provided new opportunities to travel. The use of motorised vessels threatened to make many seafaring skills redundant. Ships' engines operate independently of wind and current, while the compass provided another means of determining direction. Traditional skills continued to be used as a backup when modern technology failed or was unavailable. Some places that abandoned traditional seafaring for modern shipping and air services, however, found themselves more isolated than before when these services fell victim to commercial realities. On larger islands, jet travel led to massive out-migration. ${ }^{18}$

\footnotetext{
${ }^{15}$ William Alkire (1965) Lamotrek Atoll and Inter-Island Socioeconomic Ties, The University of Illinois Press, Urbana, p. 149 \& Alkire (1978:140-141).

${ }^{16}$ David Lewis (1978) The Voyaging Stars: Secrets of the Pacific Island Navigators, Sydney: Collins, p. 93.

${ }^{17}$ Hau'ofa (1994:155).

${ }^{18}$ Ward H. Goodenough \& Richard Feinberg (1995) "Epilogue: Seafaring in the Pacific, Past and Present", in Richard Feinberg (ed.) Seafaring in the contemporary Pacific Islands: Studies in continuity and change, De Kalb, Illinois: Northern Illinois University Press, pp. 219-230, pp. 226-227; and Michael D. Lieber (1994) More Than a Living: Fishing and the Social Order on a Polynesian Atoll, Boulder, Colorado: Westview Press, p. 11.
} 


\section{Reclaiming the Sea?}

Pockets of Islander seafaring survived the colonial era reasonably intact - especially on small, isolated islands. These oases of traditional knowledge enabled a voyaging revival to take place. A number of canoe voyages were made in the late 1960s and early 1970s between the Western Carolines and Marianas by Satawalese and Puluwatese pelu (traditional navigators) using traditional navigation. In 1976, the Carolinian navigator Mau Piailug navigated the Hokule'a, a reconstructed Hawai'ian double-hulled canoe, 2500 miles from Hawai'i to Tahiti using traditional methods.

The voyage of the Hokule'a captured the imagination of many, and inspired a voyaging renaissance. Other Islanders followed the Hawai'ian example and relearned disused arts, reconstructed voyaging canoes based on early European accounts, and sailed along old sea lanes to ancestral homes. This renaissance reached its peak at the 1992 Pacific Festival of the Arts in Rarotonga, when reconstructed canoes from across the region converged to celebrate the theme of canoe voyaging. It was designed to unify Islanders with a sense of pride in their ancestral achievements. While many academics celebrate Hau'ofa's vision of Oceania to counter the prevailing negative image of Pacific states as too small to ever be viable without heavy dependence on external aid, ${ }^{19}$ few believe it offers any way of addressing contemporary problems. Islanders now conduct most of their activities on land, and the main problems are rural poverty and those marginalised on the urban fringe. ${ }^{20}$ Most Islanders' interactions with the sea have dramatically declined since 1870. In addition, many coastal fisheries are under pressure from increased coastal populations fishing more intensively and polluting coastal areas.

Many Islanders live under laws which promote the Western concept of sea tenure. Modern fisheries are dominated by 200-mile exclusive economic zones (EEZs), instituted under the protocols of the 1982 United Nations Convention of the Law of the Sea (UNCLOS 111). Nations are entitled to exercise sovereign rights over resources 200 miles from their shores as long as they allow free air and sea passage. ${ }^{21}$ Access

\footnotetext{
${ }^{19}$ See particularly, I.G. Betram \& R.F. Watters (1985) “The MIRAB Economy in South Pacific Microstates", Pacific Viewpoint, 26(3): 497-520.

${ }^{20}$ Teresia Teaiwa (1996) review of A New Oceania: Rediscovering Our Sea of Islands, Eric Waddell et al (eds.), University of the South Pacific School of Social and Economic Development, Suva, 1993, in The Contemporary Pacific, 8(1): 214.

${ }^{21}$ Karen Nero (1997) "The Material World Remade" in Donald Denoon (ed.) The Cambridge History of the Pacific Islanders, Cambridge: Cambridge University Press, p. 368.
} 
rights within EEZs vary. Islanders in independent Pacific nations technically have more control over near-shore fisheries than those now minorities in their own land such as Maori and Hawai'ians.

Even the decolonised Island countries, however, are constrained by economic capabilities from exercising their sovereign rights. ${ }^{22}$ Modern off-shore fishing is big business. Corporations employ fleets and factory ships, sonar, and spotter planes. Island nations lack the capital to develop such huge enterprises, or even to patrol fishing in their own waters. With limited natural resources on land, demand for manufactured goods, and a pressing need to develop infrastructure, most gladly accept several million dollars annual rent for fishing rights to their EEZs and use of harbour facilities from corporations like Ting Hong. ${ }^{23}$ These stark realities animate the sense of loss that pervades Hau'ofa's vision.

Since independence, thousands of Islanders have migrated to new 'islands' on the Pacific Rim for better employment and education. From Carson City in California to Canberra in Australia they forge new lives while maintaining links with their home islands. Out-migration is one response to the economic restrictions of small island states.

Hau'ofa has been criticised for not offering practical solutions to the problems of Pacific Islands - their small size, remoteness, lack of resources, and dependence on external funding. This response views the solution in terms of natural resources rather than attitudes. The reality is that many problems cannot be solved with the resources available, but there is much that can be changed, and here lessons can be learned from the past. Hau'ofa attempts to reshape attitudes. His call for Islanders to return to seeing themselves as unified by the Pacific could be harnessed to efforts to create more regionalism in the Pacific, along the lines already embodied in agencies such as the Pacific Islands Forum and the Secretariat of the Pacific Community, as well as greater cooperation called for in initiatives such as the Pacific Plan. ${ }^{24}$

\footnotetext{
${ }^{22}$ One of the most comprehensive reviews of marine policy options in the independent Pacific is Roniti Teiwaki (1988) Management of Marine Resources in Kiribati, Suva: University of the South Pacific.

23 Christopher S. Lobban \& Maria Schefter (1997) Tropical Pacific Island Environments, Guam: University of Guam Press, pp. 274-277; Nero (1997:377-378).

${ }^{24}$ A good, recent example of this vision is Dave Peebles (2005) Pacific Regional Order, Asia Pacific Press, Canberra.
} 
While Hau'ofa is correct in asserting that his ancestors saw the Pacific as a sea of opportunity, Pacific Island history holds other lessons for today's Pacific communities. Islanders should not only have pride in the achievements of their ancestors, but also learn from them. Historically, the most successful societies in Oceania have been those that exhibit social cohesion and a high level of organisation in response to challenges from beyond the horizon, and flexibility and adaptability in dealing with such external influences. $^{25}$

\section{References}

Alkire, W.H. (1965) Lamotrek Atoll and Inter-Island Socioeconomic Ties. Urbana: The University of Illinois Press.

— (1970) "Systems of Measurement on Woleai Atoll, Caroline Islands", Anthropos, 65:1-73.

— (1978) Coral Islanders. Arlington Heights, Illinois: AHM Publishing Corporation.

Bahn, P. \& John Flenley, J. (1992) Easter Island Earth Island. London: Thames and Hudson.

Barrere, D. (ed.) (1983) Fragments of Hawaiian History, by John Papa Ii (English translation by Mary Kawena Pukui). Honolulu: Bishop Museum.

Betram, G. \& Watters, R. (1985) "The MIRAB Economy in South Pacific Microstates", Pacific Viewpoint, 26(3).

D'Arcy, P. (2005) The People of the Sea: Environment, Identity and History in Oceania. Honolulu: University of Hawai'i Press.

Diamond, J. (25 March 2004) “Twilight at Easter”, New York Review of Books.

Ellis, W. (1969) Polynesian Researches: Hawaii. Rutland, Vermont: Charles E. Tuttle Co., Publishers.

Finney, B.R. (1979) "Voyaging”, in Jennings, J.D. (ed.) The Prehistory of Polynesia. Canberra: Australian National University.

— (1984) "The Ocean and the Quality of Life", in Gopalakrishnan, C. (ed.) The Emerging Marine Economy of the Pacific. London: Butterworths.

Gifford, E.W. (1929) Tongan Society. Honolulu: Bishop Museum.

Gladwin, T. (1970) East is a Big Bird: Navigation and Logic on Puluwat Atoll. Cambridge, Mass.: Harvard University Press.

\footnotetext{
${ }^{25}$ For more detail, see Paul D'Arcy (2005) The People of the Sea: Environment, Identity and History in Oceania, University of Hawai'i Press, Honolulu.
} 
Goodenough, W.H. \& Feinberg, R. (1995) "Epilogue: Seafaring in the Pacific, Past and Present", in Richard Feinberg, R. (ed.) Seafaring in the contemporary Pacific Islands: Studies in continuity and change. De Kalb, Illinois: Northern Illinois University Press.

Hau'ofa, E. (1994) “Our Sea of Islands”, The Contemporary Pacific, 6(1).

Henry, T. (1928) Ancient Tahiti, Honolulu: BPBM.

Hughes, H. (7 May 2003) "Aid has failed the Pacific", Issue Analysis no. 33, Centre for Independent Studies.

Irwin, G. (1992) The Prehistoric Exploration and Colonisation of the Pacific. Cambridge: Cambridge University Press.

Kamakau, S. (1961) Ruling Chiefs of Hawaii. Honolulu: Kamehameha Schools Press.

Kirch, P.V. \& Green, R.C. (2001) Hawaiki, Ancestral Polynesia: an essay in historical anthropology. Cambridge: Cambridge University Press.

Lewis, D. (1977) From Maui to Cook. The Discovery and Settlement of the Pacific. Lane Cove, New South Wales: Doubleday.

— (1978) The Voyaging Stars: Secrets of the Pacific Island Navigators. Sydney: Collins.

Lewthwaite, G.R. (May 1966) "Man and the Sea in Early Tahiti: Maritime Economy through European Eyes", Pacific Viewpoint, 7(1).

Lieber, M.D. (1994) More Than a Living: Fishing and the Social Order on a Polynesian Atoll. Boulder, Colorado: Westview Press.

Lobban, C.S. \& Schefter, M. (1997) Tropical Pacific Island Environments. Guam: University of Guam Press.

Malo, D. (1951) Hawaiian Antiquities: Moolelo Hawaii, $2^{\text {nd }}$ edition (English translation by Nathanial B. Emerson). Honolulu: Bishop Museum.

Nero, K. (1997) "The Material World Remade" in Donald Denoon, D. (ed.) The Cambridge History of the Pacific Islanders. Cambridge: Cambridge University Press.

Peebles, D. (2005) Pacific Regional Order. Canberra: Asia Pacific Press.

Teaiwa, T (1996) "Review of A New Oceania: Rediscovering Our Sea of Islands, Eric Waddell et al (eds.) University of the South Pacific School of Social and Economic Development, Suva, 1993”, in The Contemporary Pacific, 8(1).

Teiwaki, R. (1988) Management of Marine Resources in Kiribati. Suva: University of the South Pacific. 